\title{
Em busca de uma história linguística
}

\author{
In search of a linguistic history
}

\author{
Esmeralda Vailati Negrão \\ Universidade de São Paulo/CNPq \\ Evani Viotti \\ Universidade de São Paulo
}

Resumo

A Linguística Histórica brasileira tem obtido grande sucesso no entendimento das mudanças pelas quais o português vem passando, desde os tempos coloniais até os dias de hoje. De maneira geral, os estudos da área enfatizam a história interna da variante a que chamamos de português brasileiro. Neste trabalho, sugerimos que é chegada a hora de abrir mais espaço para o estudo da história social de nossa língua, fazendo uma história linguística. $\mathrm{O}$ português brasileiro emergiu como um vernáculo colonial, em uma situação de extremo multilinguismo, caracterizada pelas interaçōes de falantes de línguas europeias (majoritariamente mas não apenas - o português), línguas indígenas, línguas africanas, em toda a riqueza de suas variedades dialetais. A História Linguística que aqui propomos deve buscar subsídios para reconstruir o tipo de ecologia de contato que se criou entre os falantes dessas diferentes línguas e o conjunto de traços linguísticos formado a partir desse contato. Desse modo, poderemos elaborar hipóteses a respeito da emergência das características do português brasileiro que o diferem do português europeu, dando valor à contribuição das línguas indígenas e das línguas africanas na configuração de sua gramática. 


\section{Palavras-Chave}

Português brasileiro, Contato de línguas, Línguas ameríndias, Línguas africanas, História colonial.

\section{Abstract}

The success of Brazilian Historical Linguistics in understanding the changes undergone by Portuguese since colonial times is undeniable. In general, the studies in the area emphasize the internal history of the variety that we call Brazilian Portuguese. We suggest that the time has come to start the investigation of the social history of our language, opening a new area of studies, which could be entitled Linguistic History. Brazilian Portuguese emerged as a colonial vernacular in a situation of extreme multilingualism, characterized by the interaction of speakers of European languages (mainly - but not only - Portuguese), of the many indigenous Brazilian languages, and of the many African languages brought by the slaves in all of their rich dialectal variation. The Linguistic History proposed here should gather data to reconstruct the type of contact ecology established in colonial times by the speakers of those different languages and the pool of linguistic features formed as a consequence of that contact. Hypotheses can then be proposed regarding the emergence of the characteristics that distinguish Brazilian Portuguese from European Portuguese, highlighting the contribution of the Amerindian and African languages in the configuration of its grammar.

\section{Keywords}

Brazilian Portuguese, Language contact, Amerindian languages, African languages, Colonial history. 


\section{Introdução}

1 政 $\begin{aligned} & \text { ais do que um panorama do estado da arte da Linguística Histórica feita } \\ & \text { no Brasil, este artigo traz uma discussão sobre a possibilidade de } \\ & \text { encararmos os fatos relativos à formação e evolução do português }\end{aligned}$ brasileiro sob um ângulo diferente. Para além das investigaçōes que vêm sendo feitas na área de pesquisa que se intitula Linguística Histórica, sugerimos a abertura de uma nova linha de pesquisa que estamos chamando História Linguística. Diferentemente da Linguística Histórica, que tem um foco eminentemente linguístico, essa nova linha deve ter um cunho inerentemente multidisciplinar. Suas investigações devem partir de fatos da história econômica e social do Brasil, e dos fatores geográficos e políticos que, muitas vezes, estão por trás desses fatos, para buscar uma explicação mais abrangente para o conjunto dos fenômenos linguísticos que têm sido apontados como caracterizadores do português brasileiro.

Desde Saussure, a linguística tem concentrado seus esforços na construção de seu espaço entre as ciências humanas e entre as ciências de modo geral. Para isso, durante o último século, desenvolveram-se metodologias e teorias próprias para o estudo das línguas naturais, que nos permitiram descrever empiricamente um grande número de línguas, além de nos levar à elaboração de elegantes modelos para a obtenção de uma boa adequação explicativa para essas línguas. Entretanto, para cavar seu espaço próprio no cenário científico e para conseguir sucesso em sua empreitada, a Linguística se viu em uma situação em que o diálogo com outras ciências teve que ser minimizado. Mesmo áreas que têm sido consideradas interdisciplinares (como a Sociolinguística e Psicolinguística, por exemplo), emprestam alguns conceitos e métodos de outras ciências, sem, contudo, estabelecer com elas um diálogo em que as duas fontes de saber - Linguística e Sociologia, ou Linguística e Psicologia - tenham uma posição de equilíbrio. ${ }^{1}$

Na Linguística Histórica, a situação não é diferente: a interdisciplinaridade dessa área é apenas parcial. $\mathrm{O}$ foco das investigaçoes é quase que totalmente linguístico. Vez por outra, menções são feitas a grandes fatos históricos, mas 
apenas quando eles levam a alguma ruptura mais contundente do contexto em que uma determinada língua é usada. Assim, por exemplo, no estudo da formação das línguas ibéricas, referência é feita às invasões bárbaras e árabes; no estudo do português ibérico, o período filipino que ocasionou a intensificação do contato com o castelhano é mencionado como uma possível causa para algumas mudanças linguísticas (PAIXÃO DE SOUSA, 2004); mas não se busca entender em que medida esses grandes eventos históricos se tornaram fatores responsáveis pelo estabelecimento de uma nova ordem socioeconômica, e; em que medida essa nova ordem impactou a formação e a evolução da língua falada no local.

Inegavelmente, a Linguística Histórica compartilha com a História aquilo que Paixão de Sousa (2006) chama de a contingência fundante do fazer histórico: a impossibilidade da observação direta e imediata dos fatos sob estudo. Então, como na História, ela precisa se valer do exame de documentos e do recurso de reconstituição dos fatos para construir seu saber. Além disso, do procedimento investigativo da Ciência da História, a Linguística Histórica tem tomado de empréstimo algumas assunçôes centrais para explicar o percurso pelo qual passam as línguas naturais de um momento a outro. Como nos informa Fiorin (2012), do mesmo modo que a história da humanidade já foi entendida como decadência pelos historiadores da antiguidade, também a história das línguas já foi entendida como a passagem de um estado de desenvolvimento superior, para um estado degenerado, decadente. Schleicher, por exemplo, entre outros grandes comparatistas do século 19, considerava que as línguas antigas eram superiores às línguas modernas, por terem uma morfologia mais elaborada que levava a um maior número de distinções gramaticais que, por sua vez, garantiriam uma maior capacidade de expressão.

A partir dos séculos 18 e 19, a história dos povos passou a ser vista de maneira diametralmente oposta: entendia-se que as sociedades e os indivíduos caminhavam em busca de um alto estágio de desenvolvimento. Nesse sentido, a História era vista como progresso, em um entendimento de que as sociedades se orientam para um maior nível de desenvolvimento. A Linguística Histórica também emprestou da Ciência da História essa perspectiva de progresso. Os estudiosos da evolução linguística passaram a entender que as línguas perseguem uma maior perfeição, preferindo formas sintéticas, regulares e ordem fixa, buscando uma maior expressividade, clareza e precisão, exigindo menor esforço de memória e menor esforço fisiológico na fala (JESPERSEN, 1993, apud FIORIN, 2012). 
A partir do século 20, a História deixou de ver o percurso da humanidade como tendendo a um fim, ora negativo (a decadência), ora positivo (o progresso), para buscar um posicionamento mais neutro. $\mathrm{O}$ foco dos estudos históricos se voltou para mudanças graduais pelas quais todas as sociedades humanas passam. Esse mesmo rumo vem sendo seguido pela Linguística Histórica contemporânea, que acoplou a esse ponto de vista emprestado da História uma perspectiva tomada da Biologia, segundo a qual a mudança linguística deve ser entendida como uma evolução natural.

Dentro dessa visão contemporânea de história como mudança, valiosas investidas têm sido feitas pela Linguística brasileira em busca do conhecimento da história do português brasileiro: algumas enfatizam as semelhanças com o português europeu; ${ }^{2}$ outras enfatizam as diferenças, buscando uma identidade própria para o nosso português; outras salientam empréstimos lexicais feitos a partir de línguas indígenas e africanas; outras ainda discutem possíveis interferências das línguas com que o português teve contato na formação da morfologia do português brasileiro.

Entretanto, o foco da maioria dos trabalhos de nossa linguística histórica, em consonância com a tendência geral dessa área de pesquisa, tem estado no fenômeno linguístico propriamente dito. As investigações concentram-se nas mudanças que ocorrem no interior das estruturas dos níveis fonológico, morfológico e sintático. Fazse uma história interna (MATTOS E SILVA, 2004, p. 29).

Esse foco na história interna tem sua razão de ser. Os estudos da linguagem vêm, ao longo dos séculos, buscando desvincular a língua do contexto sóciohistórico-econômico em que os homens que a usam se inserem ao longo do tempo. Segundo Weinreich, Labov e Herzog (2006[1968], p. 56), o entendimento que tem sido feito da distinção proposta por Saussure entre língua e fala é o de que Saussure estaria privilegiando a língua como fato social, em oposição ao psicologismo instaurado especialmente por Hermann Paul, no século 19. Entretanto, os autores argumentam que, mesmo assim, Saussure não chegou a fazer nenhuma contribuição no sentido de entender a língua na heterogeneidade que a caracteriza como fato social.

No âmbito da linguística de orientação chomskyana, o interesse pelos contextos sócio-históricos em que as línguas se situam éainda menor. Como é bem sabido, o conhecimento linguístico que é o objetivo de investigação dos proponentes e seguidores da gramática gerativa é de natureza interna e individual. 
Não se pode negar o sucesso obtido pela Linguística Histórica interna que vem sendo praticada dentro de um ou de outro modelo teórico, especialmente desde o século 19. Entretanto, devemos agora abrir um espaço para a história externa das línguas; ou seja, é hora de olharmos para os fatos da evolução da língua por outra perspectiva: a do contexto dos fatos históricos, sociais e econômicos em que as línguas se forjam e evoluem. Alguns trabalhos recentes já vêm demonstrando que esse é não só um caminho possível mas também uma perspectiva de olhar para os fatos linguísticos que pode trazer resultados interessantes (cf. HEINE; KUTEVA, 2005; MUFWENE, 2001, 2008; entre outros). ${ }^{3}$

No Brasil, Mattos e Silva (2004) também aponta para a necessidade de elaborarmos uma reconstituição de nossa história, conjugando fatores sóciohistóricos, demográficos e linguísticos, para podermos mapear a constituição do português brasileiro. Em palestras de caráter programático, a autora indica alguns fatores relevantes para esse projeto: (i) a demografia histórica do Brasil do século 16 ao 19; (ii) a mobilidade populacional dos africanos e afrodescendentes no Brasil colonial e pós-colonial; (iii) a escolarização ou sua ausência do século 16 ao 19; (iv) as reconfiguraçôes socioculturais, políticas e linguísticas ao longo do século 19 (p. 125). Sem dúvida, esses são fatores de grande importância para a implementação do projeto de uma história linguística do português brasileiro. ${ }^{4}$ Entretanto, nossa proposta é dar maior ênfase à elaboração de uma reconstituição histórica das relaçôes socioeconômicas subjacentes às interaçôes linguísticas que ocorreram nos séculos coloniais. Para tanto, temos de recorrer à Ciência da História para busca informação sobre as intrincadas relações que ocorriam na colônia portuguesa. A nosso ver, é isso o que vai nos permitir levantar hipóteses a respeito das causas de emergência de alguns fenômenos inovadores do português brasileiro, para além das causas que levaram esses fenômenos a se espalhar pelo território nacional. Questôes demográficas, sociocultuais e educacionais vão estar subsumidas nessa macroperspectiva de uma história linguística de base socioeconômica que aqui propomos. ${ }^{5}$ Pensamos que, só assim, vamos poder chegar a um bom entendimento do porquê, apesar da desproporção demográfica entre brancos e não-brancos durante o início da formação da nação brasileira, ${ }^{6}$ e com uma política de escolarização que se estabeleceu apenas no século 19 , não falamos hoje nem uma língua indígena, nem uma língua africana, nem um crioulo, mas uma variedade de língua de base indo-europeia.

Mas fazer essa história linguística que estamos propondo implica mais do que apenas levantar fatos históricos, econômicos e sociais que possam ser 
articulados para a construção de um maior entendimento de certos fatos linguísticos. É preciso adotar uma teoria de mudança linguística que neutralize as diferenças entre mudanças linguísticas internas e externas, e assuma que a chave de toda evolução linguística está na interação e no contato entre diferentes idioletos, dialetos e línguas. Vamos tratar dessa teoria, a seguir.

\section{Neutralizando a dicotomia entre história interna e história externa}

A separação entre história interna e história externa da evolução das línguas está, de certa forma, associada à ideia, enfatizada por Saussure, de que há dois modos pelos quais as línguas passam a divergir umas das outras: um processo natural de evolução pelo qual mecanismos internos à língua motivam algumas mudanças; ou uma ruptura do processo natural, ocasionada pelo contato de uma língua com outras línguas. Até hoje é comum o entendimento de que o estabelecimento de uma relação de parentesco entre as línguas deve ser considerado somente se a diversificação entre uma língua e outra se deve a mudanças naturais de caráter interno. Isso parece estar relacionado ao fato de que, na Linguística mais recente, o estudo do contato de línguas vem sempre atrelado à colonização das Américas, da Ásia e da África durante a expansão mercantilista europeia, e, nesse contexto, muitas das línguas que emergiram são aparentemente bem diferentes das línguas europeias. Ainda, essa posição que exclui do parentesco linguístico aquelas línguas que emergiram em situação de contato, privilegiando a visão de mudanças linguísticas internamente motivadas, está associada à ideia de pureza linguística. Essa ideia era corrente no século 19, e estava ligada, por sua vez, à ideia de pureza racial. Por essa ideia, produtos de mistura de raças ou de línguas deveriam ser considerados como desvios a um desenvolvimento natural (MUFWENE, 2001, 2008). ${ }^{7}$

Entretanto, para além do preconceito que pode subjazer essa posição, ela traz consigo dois grandes equívocos metodológicos: não é possível restringir o estudo das mudanças linguísticas por contato ao contexto da colonização europeia feita a partir do século 15 . Mufwene (2008, p. 33) apropriadamente salienta que as línguas europeias modernas não podem ser entendidas como resultado exclusivo de desenvolvimentos naturais de uma língua indo-europeia básica. Tomando o caso das línguas românicas como exemplo, elas emergiram como consequência da política de colonização empreendida pelo Império 
Romano, que levou a língua de Roma, sua cultura, seu sistema econômico e sua organização militar a várias regiōes em que existiam outras culturas, outras organizações sociais e outras línguas. Foi por causa das migrações populacionais e do contato de diferentes línguas e culturas que elas emergiram com as características que lhes são particulares. Além disso, mesmo quando se trata de explicar a própria semelhança que existe entre algumas línguas, Heine e Kuteva (2005, p. 2) observam que nem todas as características que nos dão a impressão de que essas línguas são aparentadas podem ser explicadas por herança genética. Elas podem ser causadas por diferentes razões, entre elas, o contato linguístico. Os autores salientam que o contato linguístico é um processo complexo que, em alguns casos, pode ter um papel marginal, funcionando apenas como uma alavanca para que algumas mudanças ocorram independentemente (p. 5). Mesmo assim, ele não pode ser ignorado. Para os autores, a difusão de várias características gramaticais das línguas indo-europeias, por exemplo, são devidas ao intenso contato entre elas, mais do que a um compartilhamento de características genéticas.

Partindo desse tipo de colocação, e mantendo sua ideia de que é a interação entre idioletos que propulsiona a evolução linguística, ${ }^{8}$ Mufwene $(2001,2008)$ propõe que as causas iniciais de qualquer mudança são externas à estrutura das línguas. A origem de todas as mudanças está nos atos comunicativos dos falantes, que buscam acomodar sua fala para facilitar a compreensão, ou que exaptam velhas formas para transmitir novas ideias. As acomodações mútuas entre os idioletos dos falantes fazem parte de um processo contínuo que muda os padróes de variação em uma comunidade. Sendo assim, o contato - desde o micronível interidioletal até o macronível da língua de uma comunidade - é o grande responsável pela mudança nas línguas. Com certeza, é só no nível da comunidade que os padrões trans-idioletais aparecem. Mas é importante realçar a agência dos indivíduos no processo como um todo.

A análise da mudança linguística a partir dessa perspectiva, no entanto, implica um conhecimento substancial da história não só das comunidades de fala, dos povos e das inter-relaçôes estabelecidas entre eles mas também da posição dos indivíduos na história de suas comunidades. É para esse fato que estamos querendo chamar a atenção nessa proposta de dar maior ênfase a um estudo de nossa história linguística.

É precisamente a importância dada aos fenômenos socioeconômicos e geográficos subjacentes à história de uma dada comunidade que está na base da 
argumentação feita por Chaudenson (2001), Mufwene $(2001,2008)$ e DeGraff $(2003,2004)$ contrariamente à tese de que línguas crioulas se desenvolvem a partir de pidgins. Segundo alguns dos proponentes dessa tese, ${ }^{9}$ no processo de aquisição de primeira língua, crianças de uma única geração, quando expostas a pidgins - considerados sistemas de comunicação a-sintáticos - transformamnos em línguas com uma sintaxe plena, embora a gramática resultante se caracterize por uma pobreza morfológica. Essa visão implica considerar os crioulos como uma classe especial de língua, diferente das línguas que tiveram um desenvolvimento "normal".

Entretanto, como claramente aponta Mufwene (2008, p. 35; p. 75), os locais em que pidgins se desenvolveram parecem estar em distribuição complementar com as regiōes em que as línguas crioulas emergiram. Grande parte dos pidgins de que se tem conhecimento se concentram na costa ocidental da África e nas ilhas do Pacífico. Diferentemente, os crioulos que se desenvolveram a partir de línguas europeias surgiram nas ilhas do Atlântico (especialmente no mar do Caribe, mas também em São Tomé e Cabo Verde), na costa atlântica da África, e em algumas ilhas e costas do oceano Índico. Essa distribuição de natureza geográfica associada à história da expansão imperialista europeia, por si só, já lança dúvidas sobre a ideia do contínuo pidgin-crioulo.

Quando se investiga o tipo de relação socioeconômica que se estabeleceu nos locais onde emergiram pidgins e onde emergiram crioulos, vê-se que há uma diferença substancial entre as duas ecologias. Nos locais onde surgiram pidgins, a ocupação e a colonização se iniciaram pelo modelo de troca, que se caracteriza por envolver contatos esporádicos, em um tipo de relaçáo limitada entre os nativos e os europeus. Muitas vezes, esses encontros eram inicialmente mediados por intérpretes; entretanto, à medida que o comércio se intensificava, um maior número de nativos passava a tentar falar a língua europeia, fazendo com que o sistema de comunicação usado se distanciasse mais e mais tanto da língua falada pelos europeus quanto da língua falada pelos nativos. E, em alguns casos, esse sistema de comunicação se tornou tão funcional que passou a ser usado com mais regularidade, ganhando maior estabilidade e maior complexidade. Dois exemplos de desenvolvimentos de pidgins a línguas vernáculas são o caso do tok pisin, falado em Papua Nova Guiné, e o inglês pidgin nigeriano (MUFWENE, 2008, p. 76).

Diferentemente, as línguas crioulas emergiram nos assentamentos das colônias de grandes latifúndios agrícolas, nas quais a maioria da população era não europeia. A explicação oferecida convincentemente por Mufwene é a de que 
o sistema socioeconômico dessa configuração colonial teve uma fase inicial, em que os não europeus tinham um contato razoavelmente regular com os europeus. Nessa fase, os assentamentos eram distantes uns dos outros e o número de não europeus em cada um deles era pequeno. Em um grande número de casos, quando havia mais de um escravo, eles não falavam a mesma língua. Portanto, era natural que a comunicação fosse feita por meio do uso da variedade da língua europeia dos colonos, o que alavancava o processo de aquisição dessa língua como segunda língua pelos não europeus. Ainda nessa fase inicial, os filhos dos escravos eram pouco expostos às línguas nativas de seus pais e provavelmente tinham mais interesse em aprender a se comunicar na língua vernácula que surgia. Essas crianças provavelmente passavam o dia longe de seus pais, e sua língua se desenvolvia pelas interações que elas tinham entre si, e não pela interação que elas tinham com os pais. Além disso, Mufwene ressalta outro fator importante para o entendimento da formação das línguas vernáculas que emergiam nesses contextos: a variedade falada pelos trabalhadores forçados (indentured servers) que, apesar de europeus, na maioria das vezes não falavam a mesma língua que os colonos.

À medida que mais escravos chegavam às colônias, a população de falantes não nativos da língua europeia foi suplantando a população de europeus, fazendo com que as línguas não europeias passassem a exercer um papel mais relevante na formação dos novos vernáculos. E, passada a fase inicial de colonização, com a expansão do sistema de grandes latifúndios agrários e o aumento do número de escravos, uma nova relação social teve início: a segregação. Esse foi um fator chave para alimentar ainda mais as diferenças entre a língua falada pelos escravos e aquela falada pela população de origem europeia.

Vejam, então, como o entendimento da história de uma população, e dos relacionamentos socioeconômicos entre os grupos e comunidades que a constituem, é de fundamental importância para o entendimento da história de sua língua. A nosso ver, para entender a formação do português brasileiro, precisamos, antes, buscar estreitar o diálogo com a história econômica e social do Brasil, especialmente a do período colonial. 


\section{Para um início de história linguística do Brasil}

\section{Preliminares sobre a história linguística da perspectiva da relação com a África}

Alencastro (2000) apresenta uma proposta ousada sobre a formação da nação brasileira. A constituição do Brasil como nação não teria tido início do modo como normalmente se pensa, a partir da ocupação e da colonização do que se entende como o território colonial brasileiro. Para Alencastro, a formação da nação brasileira se deu a partir de fortes relações econômicas mantidas entre o Brasil e Angola, desde o século 16 até o fim do tráfico, em meados do século 19, em um espaço transcontinental constituído pelas rotas marítimas que ligavam Portugal, Brasil e África ocidental.

Nós vivemos na ilusão de que, desde o começo de nossa história, havia um todo colonial que, grosso modo, correspondia ao território que tinha sido estabelecido como português pelo Tratado de Tordesilhas. Mas, as coisas eram bem diferentes. Até meados do século 18, as populações que habitavam o litoral que ia de Recife ao Rio de Janeiro e as populações que habitavam o norte e o sul do território tinham muito pouco contato entre si. Por terra, as distâncias eram extremamente longas e os caminhos estavam ainda por ser abertos. Por mar, as correntes marítimas não favoreciam o deslocamento entre essas regiōes. Um dos exemplos dados por Alencastro é o da expedição de Raposo Tavares, que saiu de São Paulo em 1648 com 1200 bandeirantes e chegou, pelo sertão, a Belém do Pará, em 1651. Para voltar, eles tiveram que ir até Lisboa para, de lá, pegar o navio de volta para a costa sudeste do Brasil. Se eles tivessem tentado ir de barco de Belém para o sul, eles teriam ido parar na Guiana. Diferentemente, as correntes marítimas e os ventos facilitavam a navegação da costa brasileira abaixo de Pernambuco para a costa do Benim e de Angola.

Segundo Alencastro, há ainda outro fato que indica que as populações das diferentes partes do território brasileiro tinham maior proximidade administrativa e comercial com populaçôes externas ao Brasil do que entre si. Após a segunda metade do século 17, com a reorganização da estrutura da Igreja Católica portuguesa, foi criada uma nova diocese no Maranhão. Curiosamente, essa nova diocese foi colocada sob a autoridade do arcebispado de Lisboa, e não daquele criado na Bahia. Ao mesmo tempo, a diocese de Luanda, em Angola, foi submetida à autoridade do arcebispado da Bahia, e não do de Lisboa. 
Ainda de acordo com Alencastro, essa estreiteza entre o Brasil e a África se manteve até bem depois da independência, com o Império acobertando o tráfico ilegal de escravos. Essa política do Império visava a proteger a oligarquia rural responsável pela economia agrícola de exportação que, por sua vez, era o grande sustento do Império.

Esse espaço transatlântico criado a partir da maior facilidade de navegação entre o Brasil e a África deve ter sido um dos fatores que contribuíram para que o tráfico de escravos para o Brasil tivesse rapidamente deixado de seguir um modelo triangular que envolvia Portugal. De acordo com Bonvini (2008), a partir do final do século 16, a coroa portuguesa abriu mão do monopólio sobre o empreendimento comercial da escravidão de africanos, autorizando comerciantes portugueses que viviam no Brasil a capturar escravos na África e trazê-los diretamente para cá. Com isso, o braço da viagem que envolvia o transporte dos escravos para Portugal foi excluído da transação. ${ }^{10}$ No início do século 18 , várias companhias particulares brasileiras já tinham se tornado as responsáveis diretas pelo tráfico de escravos entre a África e o Brasil. ${ }^{11}$

Que importância tem tudo isso para a História Linguística que aqui propomos? Inseridos em uma visão de história interna da língua, muitos são os trabalhos que têm procurado reforçar as semelhanças do português brasileiro com o português europeu, desconsiderando a importância do contato de línguas que se verificou durante o período de ocupação e colonização do território brasileiro. Do mesmo modo que Silva Neto afirma que, na constituição do português brasileiro, "a linguagem adulterada dos negros e índios não se impôs senão transitoriamente" (1960, p. 21), Naro e Scherre (2007) reforçam que muitas das características fonológicas e morfossintáticas do português brasileiro, ${ }^{12}$ que o diferenciam do português europeu, são resultantes de um processo de deriva linguística. ${ }^{13}$

Em outras palavras, para Naro e Scherre, as características do português brasileiro contemporâneo são desenvolvimentos naturais do português arcaico e clássico. Por isso, elas não podem nem devem ser explicadas como fruto do contato do português com as línguas indígenas do Brasil ou com as línguas trazidas pelos escravos africanos, nem como o resultado de um processo de transmissão imperfeita no processo de aquisição de língua. Embora os autores admitam a importância do contato com os povos africanos e indígenas na constituição da cultura brasileira, seu entendimento parece ser o de que três séculos de multilinguismo não impactaram sobremaneira a formação da gramática da língua falada hoje no Brasil. ${ }^{14}$ 
Entretanto, quando incorporamos à reflexão os fatos geográficos e históricos apontados por Alencastro, de um lado, e Bonvini, de outro, parecenos difícil sustentar a ideia de uma deriva natural do português clássico para o português brasileiro, em um percurso relativamente homogêneo através dos séculos e em todo o território colonial. Primeiramente, a regionalização parece ser um fator importante a ser levado em conta. $\mathrm{O}$ fato de haver diferentes agrupamentos populacionais em locais distantes uns dos outros, alguns mantendo uma maior proximidade social, econômica e política com Portugal, outros, com a África, já indica que o contato com o português europeu não era uniforme em todo o território. Em segundo lugar - e levando em consideração apenas a vizinhança socioeconômica do Brasil com a África - quando o tráfico de escravos deixou de seguir o modelo triangular para ser feito diretamente entre o Brasil e a África, deixou de lado também o contato com a língua falada na metrópole. Com isso, os escravos fundamentalmente interagiam com brasileiros ou europeus que já viviam no Brasil há algum tempo, e que certamente falavam uma língua que já tinha se afastado da língua falada em Portugal.

Mas isso não é tudo. Segundo Bonvini (2008), a história nos informa que uma das mais antigas políticas do comércio de escravos africanos praticada pelos portugueses era misturar diferentes grupos étnicos e linguísticos para evitar levantes e planos de fuga. Desde a segunda metade do século 16, eles vendiam, em um porto, escravos que eles tinham capturado em outro. Com isso, povos africanos de diferentes origens, falando diferentes línguas, já se misturavam bem antes de cruzar o Atlântico.

Ainda, entre os séculos 16 e 17, houve uma alteração na estratégia de captura de escravos. Depois de um período inicial caracterizado por violentas investidas de captura, estabeleceu-se uma nova modalidade mais branda de apreensão de novos cativos, que ficava sob a responsabilidade de comerciantes de origem africana ou mista, conhecidos como pombeiros. Os pombeiros eram negros ou mulatos, vinham de várias regiōes, pertenciam a etnias diferentes, e tinham diferentes línguas nativas. De alguma maneira, eles deviam se comunicar entre si e com os europeus. Eles também se comunicavam com as mais variadas tribos do interior da África, trocando tecidos e outros objetos por escravos. Após a captura, os escravos eram levados para a costa, onde tinham de esperar alguns meses pelo próximo navio negreiro que iria transportá-los para o Brasil. Durante a espera, nativos de diferentes etnias e diferentes línguas eram mantidos juntos como prisioneiros em construçōes conhecidas como barracôes, e frequentemente 
precisavam trabalhar juntos para plantar sua própria comida. Em seguida, passavam outros quase dois meses juntos nos navios que cruzavam o oceano em direção ao Rio de Janeiro, a Recife, ou a Salvador.

Como bem aponta Bonvini (2008), esse tipo de organização, especificamente desenvolvido para o tráfico de escravos com o Brasil, criou uma situação de multilinguismo na África, em que falantes de línguas africanas diferentes embora próximas - eram forçados a interagir entre si, com pombeiros e com falantes de diferentes dialetos do português. Bonvini $(2008,2009)$ sugere que, no caso do tráfico estabelecido com Angola, é provável que o quimbundo de Luanda tenha sido usado como língua veicular nos barracões e nos navios, e que algumas variedades do português já fossem familiares a alguns dos cativos. Sendo assim, a ecologia multilíngue que os escravos viriam a encontrar no Brasil não era nova para eles.

Essa reflexão vai no sentido de justamente apontar que, quando abordamos a origem e formação do português brasileiro a partir dos fatos apurados por meio de investigações históricas, não podemos minimizar o peso que uma configuração de extremo contato de línguas deve ter tido na emergência das peculiaridades que distanciam a variedade linguística brasileira da europeia.

\section{Preliminares sobre a história linguística da perspectiva da relação com as tribos indígenas}

Até hoje, uma descrição detalhada da população europeia que permaneceu por algum tempo no território da nova colônia, quer para explorá-lo, quer para colonizá-lo, ainda está para ser feita pelos estudiosos do contato de línguas no Brasil. Com certeza, não deve haver uma documentação abundante que traga um levantamento minucioso sobre os tripulantes dos primeiros navios portugueses que chegaram à costa brasileira, nem dos colonos que vinham com eles. A falta de mapeamento dessa população europeia inicial reforça a ideia equivocada de que, de um ponto de vista linguístico, havia uma homogeneidade na população europeia que aqui chegava. A noção ingênua que acabamos formando é a de que todos falavam português, e, pior, um único dialeto do português - aquele dos letrados que redigiam documentos oficiais, cartas para seus superiores e obras literárias.

Sabe-se que, até aproximadamente 1530, a coroa portuguesa enviava navios para o Brasil com dois objetivos: guardar a costa, protegendo a nova colônia 
da invasão de piratas; e extrair o tão valioso pau-brasil. Nesses navios, vinham basicamente homens. A maioria deles era de origem portuguesa, mas não todos. Havia europeus de outras nacionalidades e línguas. Como pessoas envolvidas na expansão imperial europeia, esses homens certamente deviam estar acostumados a situações de contato linguístico, e provavelmente já deviam ter desenvolvido eficientes estratégias de comunicação com falantes de línguas diferentes.

Como visto acima, o contato dos portugueses com diversos povos africanos em sua exploração da costa ocidental da África a partir do século 15 gerou uma situação linguística bastante relevante para formarmos uma ideia menos purista sobre a língua que os europeus trouxeram para cá. Sabe-se que um sistema de comunicação utilitário desenvolvido no contato dos portugueses com os africanos era conhecido em Portugal desde a segunda metade do século 15. Esse sistema de comunicação era conhecido como língua de preto ou fala da Guiné, e, uma ideia do que ele foi chegou até nós por paródias feitas por autores brancos, que tinham pouco contato com aqueles que efetivamente usavam esse sistema. Apesar dessa distorção, alguns elementos são verídicos e aparecem nos crioulos de base portuguesa, nos bairros populares das cidades de Angola e Moçambique e no vernáculo brasileiro (LIPSKY, 2009). Segundo Naro e Scherre (2007, p. 27), o uso desse sistema não era limitado à interação de portugueses com africanos, mas ele era tão difundido que chegava a ser usado na interação com falantes de espanhol também. Isso sugere que traços de outras línguas deviam também fazer parte desse sistema de comunicação.

Com essas considerações estamos procurando construir um quadro mais realista do que foi o português que chegou ao Brasil nas naus de patrulhamento e exploração de pau-brasil. Não se tratava de um português único, mas de uma multiplicidade de dialetos portugueses; não se tratava de um português "puro", mas de um português que já carregava marcas do contato com uma variedade de línguas africanas e com as línguas de outros europeus que participavam da expansão mercantilista. Uma vez em território brasileiro, as relações entre os europeus e as diversas populações indígenas que viviam na costa brasileira certamente devem ter causado o surgimento de um sistema de comunicação funcional que permitisse a interação entre eles.

A questão de o que era esse sistema de comunicação é bastante complexa. A informação encontrada na literatura parece desencontrada. Alguns o chamam língua geral. Baseados em Silva Neto (1980[1950]), Naro e Scherre (2007, p. 28) nos informam que a língua geral era um pidgin ou uma koiné simplificada de 
base tupi, que foi usada até o início do século 18 em uma vasta extensão da colônia. No mesmo sentido, Sampaio (1987[1901], p. 69) nos informa que, até o início do século 18 , a proporção entre falantes de tupi e de português na colônia era de três para um.

Mas aqui algumas questões se levantam. Primeiro, o que era esse tupi mencionado por Sampaio? Será que ele se referia apenas à língua falada pelos povos indígenas, ou ele incluía também as chamadas línguas gerais? Se a referência era à língua falada pelos índios, de qual variedade especificamente ele estava falando? Segundo, o que exatamente são as chamadas línguas gerais? Terceiro, hoje sabemos que houve duas línguas gerais no Brasil colonial: uma falada na região de São Paulo, levada pelos bandeirantes para o interior do território, chamada, muitas vezes, língua geral paulista; outra, conhecida como língua geral amazônica ou nheengatu, usada na região amazônica (RODRIGUES, 1996, p. 11). De que língua geral Naro e Scherre estão falando? Será que as duas tiveram o mesmo tipo de formação? Provavelmente, não, apesar de ambas terem base tupi. E, aqui, uma outra questão se coloca: qual variedade linguística da família tupi-guarani constituía a base de uma e outra dessas línguas gerais?

Altman (2003, p. 58) observa que, tecnicamente, no contexto da colonização das Américas, o termo lingua geral é usado para fazer referência às línguas nativas escolhidas pelos europeus para funcionar como língua veicular em suas interações com as populações indígenas. Assim foi na América espanhola, por exemplo, em que o quéchua foi considerado uma língua veicular suprarregional (DIETRICH; NOLL, 2010, p. 81). Nessa mesma acepção, no caso do Brasil, a administração portuguesa escolheu, como língua geral, a língua tupi - uma das línguas da família tupi-guarani com as quais os portugueses tiveram contato desde o século 16. Segundo Dietrich e Noll, a designação tupi vem do nome tupinambá, usado inicialmente para fazer referência à língua dos índios tupinambás. $\mathrm{O}$ tupinambá era a língua mais comum na costa brasileira da primeira metade do século 16 , e foi chamada língua brasílica pelos portugueses.

Entretanto, apesar de o tupi ter sido escolhido pela administração colonial como língua geral no sentido técnico, ele não pode ser confundido com o que veio a se chamar língua geral paulista ou língua geral amazônica. ${ }^{15}$ De acordo com Altman (2003, p. 67), a língua geral paulista se desenvolveu a partir do tupiniquim, a língua falada pelos índios que habitavam a região de São Paulo e São Vicente. ${ }^{16} \mathrm{O}$ nheengatu teria se formado mais tarde, a partir da língua falada 
pelos índios tupinambás habitantes da região do Maranhão. ${ }^{17}$ No mesmo sentido, Rodrigues (2010, p. 29) nos informa que a língua geral paulista era uma variedade falada pelos bandeirantes que, em sua maioria, eram filhos de mães tupis e pais portugueses, e que essa variedade era diferente da língua dos índios tupis.

Não nos parece clara a diferença que os autores têm buscado estabelecer entre as duas línguas gerais. ${ }^{18}$ Pelas informações arroladas acima, a diferença parece estar unicamente no fato de que uma se formou a partir do tupiniquim e outra a partir do tupinambá. Mas qual é exatamente a diferença entre essas duas variedades linguísticas? Dietrich e Noll (2010, p. 82) dizem que o tupinambá da região de Salvador foi a língua escolhida pelos jesuítas para a catequização dos índios. Essa língua foi aprendida por Manoel da Nóbrega e João de Azpicuelta Navarro e foi ensinada, em seguida, para José de Anchieta, tendo funcionado como língua veicular para os índios de diferentes tribos e para os missionários. Segundo os autores, essa é a língua descrita por José de Anchieta em sua gramática do tupi. Apesar de Anchieta ter se mudado para São Vicente logo após sua chegada - e, apesar de que, nessa região, pelo que se depreende das informaçôes levantadas, falava-se uma variedade diferente do tupi - parece que sua gramática não foi escrita durante sua permanência em São Vicente, mas, sim, quando ele retornou à Bahia, alguns anos mais tarde. Dietrich e Noll ponderam que Anchieta devia ter conhecimento das diferenças entre as variedades linguísticas das duas regiões, embora não as tenha explorado em sua gramática. Será que as diferenças eram tão notáveis a ponto de ser consideradas a grande e única razão para a separação entre as duas línguas gerais?

Além disso, de um ponto de vista de uma teoria de contato linguístico, o estatuto das línguas gerais faladas no Brasil durante a colônia também não está claro. Como visto acima, Mufwene (2008) argumenta que pidgins são meios de comunicação reduzidos, baseados em contato esporádico entre populaçóes de línguas diferentes. Desse modo, eles estão em distribuição complementar com crioulos e outros vernáculos coloniais, que, por sua vez, emergem de contatos prolongados. O fato de a ocupação do território colonial brasileiro ter se iniciado como um modelo de exploração e comércio, com contatos breves entre europeus e os povos indígenas indica que, nesses primeiros 30 anos de ocupação, um ou vários pidgins devem ter surgido ao longo da costa do Brasil. Mas será que esses pidgins têm alguma relação com o que mais tarde veio a se chamar línguas gerais? Certamente, se as línguas gerais foram usadas por séculos durante a era colonial, elas não podem simplesmente ser consideradas como sistemas de comunicação 
simplificados do tipo pidgin. Elas devem ter alcançado um certo nível de complexidade e estabilidade estrutural, o que nos faz pensar que elas eram verdadeiras línguas vernáculas. Mas, aqui, é necessário fazer outra pergunta: qual é a relação entre essas línguas gerais, e o tupi(nambá/niquim) aprendido pelos missionários europeus e usado como língua veicular em sua comunicação com os índios, e usado pelos próprios índios falantes de diferentes variedades da língua?

Dietrich e Noll (p. 83-84) parecem acreditar que a língua usada pelos missionários e descrita nas gramáticas era bastante fiel à fala dos índios. ${ }^{19}$ Sua argumentação é a de que poucos missionários não poderiam modificar a estrutura da língua dos milhares de índios que viviam próximos a eles. Seu entendimento parece ser o de que o tupinambá falado pelos missionários era bem diferente das línguas gerais impuras [sic] faladas pelos mestiços nas regiōes mais afastadas das missões. Que deveria haver diferenças entre a apropriação do tupinambá pelos jesuítas e por aqueles que viviam afastados das missões, adentrando o interior do território, parece-nos inquestionável. Entretanto, consideramos pouco provável que, no caso dos missionários, a aquisição da língua indígena não tenha sofrido os percalços por que passa todo processo de aquisição de segunda língua por adultos. A nosso ver, em nenhum dos casos, a língua falada pelos europeus ou mestiços poderia ser considerada tão próxima da língua falada pelos índios como, muitas vezes, a literatura faz crer. Essa visão, no entanto, precisa ser entendida no quadro de uma teoria de contato linguístico, que vamos apresentar mais adiante. De um jeito ou de outro, certamente é necessário avançar as pesquisas para poder responder às questóes levantadas. E esse avanço depende substancialmente do estudo das características sociais e econômicas do contato entre os europeus e os povos nativos do Brasil, tanto dentro quanto fora das missões.

\section{Um modelo de teoria de contato e mudança linguística}

O projeto de investigação de nossa história linguística que aqui propomos não terá sucesso se não for acompanhado de uma teoria de contato e mudança linguística que tenha abertura para dar a fatos sócio-históricos, econômicos e geográficos o peso que eles merecem ter. A teoria da evolução linguística proposta por Mufwene (2008) é um exemplo de modelo que altera radicalmente a visão de mudança linguística. Ela não só permite a inclusão de fatos de natureza socioeconômica na equação de análise da mudança, mas, mais do que isso, estabelece que não é possível entender a mudança linguística em sua inteireza 
sem levar em consideração toda a situação histórica, econômica e social em que ela se forjou.

Mufwene estabelece um paralelo entre a pesquisa sobre a mudança linguística e a evolução das espécies. Ele prefere aplicar à língua o termo evolução ao termo mudança, porque, a seu ver, a evolução de uma língua deve ser entendida como uma resposta adaptativa às diferentes condições ecológicas criadas no contato entre populaçôes. Nesse sentido, sua proposta anula a distinção já clássica na literatura sobre contato linguístico entre línguas crioulas e línguas não crioulas, considerando ambas como resultantes de um processo de especiação linguística. ${ }^{20} \mathrm{~A}$ diferença entre elas adviria das particularidades das condições ecológicas em que elas teriam emergido.

Segundo Mufwene, o contato linguístico está na base de todos os processos de mudança, até mesmo daqueles que, equivocadamente, têm sido explicados como motivados por um processo de regulação interna do sistema da língua. Mais do que isso, o contato está na base de toda a diversidade observada entre as línguas do mundo. E cada situação de contato é uma ecologia diferente que tem que ser analisada em sua especificidade.

Mufwene concebe a língua como uma espécie biológica cujos membros são os idioletos de cada falante. Do mesmo modo que nenhum membro de uma espécie biológica é exatamente igual a outro, nenhum idioleto é igual a outro. Quando um ou mais indivíduos interagem em eventos comunicativos, eles acomodam mutuamente os seus idioletos, fazendo com que certos traços convirjam para que a comunicação seja bem sucedida. É por essa interação entre indivíduos que os traços de um idioleto contaminam os traços de outro, ocasionando mudanças constantes e graduais na língua comum.

Em situações ecológicas em que falantes de línguas diferentes interagem, o mesmo processo de acomodação de idioletos ocorre. A diferença nesse caso é que os idioletos em contato são membros de diferentes espécies, ou seja, de diferentes línguas. Mesmo nesse caso, os falantes vão adaptar seu idioleto individual para facilitar a comunicação, adotando traços das diferentes línguas em contato, reorganizando-os de modo a torná-los mais compatíveis. Em alguns casos, é possível que essa nova organização de traços se espalhe, atingindo outros falantes nativos da língua, pouco a pouco, num processo lento e gradual que inclui cada ato comunicativo em cada evento do qual eles participam. Quando essas adaptações alcançam o estatuto de norma comum, uma nova variedade 
linguística nasce. Se essa nova variedade vai ter ou não características do tipo daquelas que têm sido atribuídas às línguas crioulas vai depender do tipo de situação social e econômica em que o contato de idioletos se deu. Como já mencionado, as variedades conhecidas como línguas crioulas emergiram em situações históricas particulares, em que a população que já tinha tido contato com a língua dominante (a ponto de iniciar a aquisição de uma segunda língua) foi segregada, deixando de interagir com falantes nativos da língua dominante.

A teoria de Mufwene coloca, então, um sério desafio para aqueles que investigam a formação do português brasileiro. Seus objetivos devem necessariamente centrar-se numa cuidadosa análise do contato estabelecido entre:

i. as variedades do português que chegaram aqui, nos diferentes fluxos da empresa colonial;

ii. as incontáveis línguas indígenas nativas aqui encontradas; e

iii. todas as línguas e dialetos que foram trazidos pelos africanos para o Brasil, das mais diversas partes do continente africano, em diferentes momentos e configuraçōes do tráfico.

Tudo isso deve ter início em uma profunda investigação da história da colonização e das relações socioeconômicas subjacentes às interaçôes entre os membros da população colonial. Eis aí a razão pela qual delineamos, neste artigo, algumas das grandes questōes que precisamos buscar responder ao procurar fazer nossa história linguística.

Mas essa não é a única tarefa que a teoria de Mufwene nos propõe. Como Mufwene associa as línguas às espécies biológicas, ele lança a hipótese de que elas se constituem por meio de um processo amplo de competição e seleção. No caso das espécies biológicas, a competição e a seleção se dão entre genes. No caso das línguas, a competição e seleção se dão entre os traços linguísticos dos idioletos em interação. Variantes alternativas de realizações fonéticas e prosódicas, de itens lexicais, de estruturas morfossintáticas, de estruturas de informação, de restrições pragmáticas, em situações de interação, passam a integrar um banco de traços, ${ }^{21}$ e passam a competir em um processo de seleção.

Sendo assim, a investigação sobre a emergência do português brasileiro tem que se voltar também para as propriedades gramaticais das línguas que participaram de sua formação. Mais especificamente, deve-se observar não só os traços das 
línguas que funcionaram como superstrato ou substrato, ${ }^{22}$ mas também a possível congruência entre os traços das línguas em contato, que pode, por sua vez, exercer influência no processo de seleção entre as alternativas em competição.

Com o intuito de exemplificar análises baseadas na ideia da formação de um banco de traços linguísticos em situações de contato de línguas, apresentamos uma hipótese que vimos elaborando a respeito de construções particulares do português brasileiro, que o distinguem do português europeu e de outras línguas românicas (NEGRÃO; VIOTTI, 2010, 2011). Alguns exemplos dessas construções são os seguintes:

1. O Luiz Omar nunca torceu tanto para um saque errar.

2. Não tem nenhum concurso que anulou por causa do mérito.

3. Eu fiquei com tanto medo que o sanduíche nem engoliu.

Em Negrão e Viotti (2010), apresentamos uma análise sintáticosemântica para essa construção do português brasileiro, que exibe uma estratégia de intransitivização inexistente no português europeu. Tratamos essas sentenças como instâncias de uma construção absoluta, por apresentarem um verbo prototipicamente transitivo não pertencente à classe dos verbos de alternância causativa, usado na forma ativa com apenas um argumento, o temático. A semântica associada a construções absolutas é a de que o participante do evento responsável por ele é totalmente eliminado de sua conceitualização, fazendo com que a sentença tenha uma leitura impessoal. ${ }^{23}$

Em Negrão e Viotti (2011) lançamos a hipótese de que essas construções do português brasileiro, que o distinguem do português europeu e de outras línguas românicas, resultaram de um processo de seleção operado sobre um banco contendo traços morfossintáticos do português europeu do século $16 \mathrm{e}$ do quimbundo. ${ }^{24}$ Esse banco de traços teve origem na situação de multilinguismo vigente no Brasil no período colonial. Mais ainda, hipotetizamos que a congruência parcial observada entre os traços estruturais das línguas em contato levou a uma reinterpretação dos dados de ambas as línguas.

Os passos da argumentação lá desenvolvida são os seguintes. Tomemos um dado significativo do português do século 16, analisado por Paixão de Sousa (2008):

4. El Rei ${ }_{i}$.............[Uma chamada Dona Urraqua $]_{j}, \varnothing_{i}$ casou $t_{j}$ com o Conde Dom Reymão de Tolosa (CTB7) 
De acordo com Paixão de Sousa, a interpretação da sentença4 é a de um evento externamente causado no qual o rei fez com que uma de suas filhas, Dona Urraqua, se casasse com o Conde Dom Reymão de Tolosa. Para dar conta dessa interpretação, a seguinte estrutura é proposta:

5. $[\mathrm{DP}$ tema/objeto deslocado $]\left[\varnothing_{\text {sujeito anafórico }}\right]\left[\mathrm{V}_{\text {forma ativa }}\right]$

A estrutura em 5 representa as seguintes propriedades:

- o sujeito do verbo casar é uma categoria vazia do tipo anáfora zero, coindexada com um sintagma nominal, El rei, introduzido previamente no discurso. $\mathrm{O}$ constituinte vazio expressa o papel semântico de causador; e

- o objeto do verbo é um sintagma nominal uma chamada Dona Urraqua, que expressa o papel semântico de tema. Esse objeto, no entanto, não é realizado na posição canônica dos objetos, ou seja, na posição pós-verbal. Ele foi deslocado para uma posição no início da sentença.

Segundo Paixão de Sousa, essa sentença exemplifica a estrutura canônica das sentenças do português do século 16, cujas propriedades básicas são:

i. objetos não agentivos são deslocados para uma posição na periferia esquerda das sentenças;

ii. argumentos agentivos / causativos aparecem na posição de sujeito das sentenças;

iii. há uma forte preferência por sujeitos nulos.

Queremos ressaltar que, apesar do deslocamento dos objetos não agentivos para a posição pré-verbal, a interpretação da sentença ainda é causativa.

Tomemos agora alguns dados do quimbundo, em que, diferentemente do que ocorre na construção do português do século 16 apresentada acima, o deslocamento do objeto para a periferia esquerda da sentença pode acarretar uma interpretação próxima a de uma sentença passiva (GIVÓN, 2002).

6. Exemplo 6.b de Givón:

$\begin{array}{lll}\text { Nzua ana a- } & \text {-mu- mono } \\ \text { John } & \text { children } & \text { they- }\end{array}$

John, the children saw him 
7. Exemplo 6.c de Givón:

Nzua $\quad \varnothing \quad$ a- $\quad-$ mu- mono

John $\varnothing$ they- -him- saw

John, they saw him (anaphoriclactive)

John, he was seen (impersonal passive)

Em (6) e (7), o objeto $N z u a$ 'João', que carrega o papel semântico de tema, está deslocado para uma posição na periferia esquerda da sentença. Em (6), a posição de sujeito está ocupada pelo constituinte aana 'crianças', ao passo que em (7) o argumento ocupando a posição de sujeito é uma categoria vazia. Quimbundo tem morfologia flexional de concordância com o sujeito e com o objeto prefixadas ao verbo, ou seja, a- e - mu- concordam com aana e $N z u a$, respectivamente. É importante notar que a sentença (7) é ambígua e essa ambiguidade está relacionada ao papel do prefixo $a$ - Em uma leitura, o morfema é anafórico e serve para a identificação do sujeito nulo: ele se refere ao grupo de pessoas que viu Nzua. Nesse caso a sentença tem uma interpretação ativa. $\mathrm{Na}$ segunda interpretação, o prefixo $a$ - funciona como uma marca de impessoalização, fazendo com que a sentença tenha uma interpretação semelhante à interpretação das sentenças passivas.

A estrutura associada à sentença (7) é a seguinte:

8. [ $\left.\mathrm{DP}_{\text {tema/objeto deslocado }}\right]\left[\varnothing_{\text {sujeito/ leitura impessoal }}\right]$ [ clítico objeto $\left.\mathrm{V}_{\text {forma ativa }}\right]$

Como é fato que, no período colonial, houve grande e duradoura interação linguística entre falantes de português e de quimbundo, tanto na África quanto no Brasil, é plausível supor que:

i. um banco de traços linguísticos tenha se formado como fruto dessa interação, integrando estruturas do português e do quimbundo como as em 5 e 8 e, entre outras estruturas dessas mesmas línguas e de outras línguas participantes da situação de contato instaurada;

ii. esses traços tenham entrado em competição; e

iii. traços congruentes dessas estruturas tenham tido mais chances de ser selecionados para a constituição da língua vernácula colonial que se formava. 
Voltemos, agora, para as sentenças do português brasileiro exemplificadas de 1 a 3 acima. Elas podem ser representadas pela seguinte estrutura:

9. [ $\left.\mathrm{DP}_{\text {tema/objeto deslocado }}\right]\left[\mathrm{V}_{\text {forma ativa }}\right]$

Nossa hipótese é a de que essas construções do português brasileiro emergiram, com as características que têm (semântica impessoal com verbo na forma ativa), como fruto:

i. da congruência de traços comuns ao português clássico e ao quimbundo, que são o deslocamento do complemento do verbo para uma posição pré-verbal e a manutenção do verbo na forma ativa; e

ii. da semântica impessoal da construção do quimbundo.

Essa hipótese de processo de competição e seleção de traços a partir de um banco de traços oriundo do contato entre português e quimbundo na emergência do português brasileiro pode ser representada pela figura abaixo:

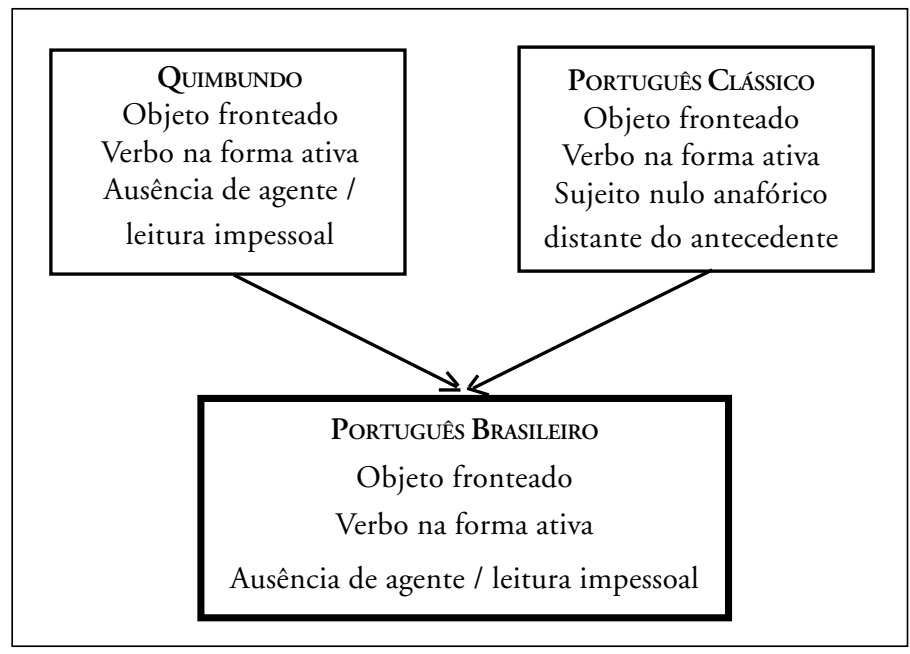

\section{Considerações finais}

É importante, uma vez mais, ressaltar que a exemplificação que apresentamos para ilustrar a operacionalidade da proposta de Mufwene, valendo-nos do contato atestado entre o português do século 16 e o quimbundo, deve ser 
sempre considerada como uma hipótese parcial. Em primeiro lugar, não podemos saber garantidamente se as estruturas do português e do quimbundo que estamos levando em consideração eram efetivamente parte dos idioletos dos portugueses e africanos que interagiam de forma regular na colônia. A proposta de estrutura canônica do português clássico de Paixão de Sousa (2008) foi elaborada a partir de dados obtidos em textos escritos. Não temos como apurar se ela era também a estrutura canônica dos dialetos do português dos navegadores que atingiram a costa oeste da África, dos primeiros exploradores do Brasil e dos colonizadores que os seguiram. Quanto aos dados do quimbundo, trata-se de estruturas da língua contemporânea. Não temos como saber com certeza se essas estruturas já se encontravam nas variedades faladas pelos escravos trazidos para cá.

Em segundo lugar, não podemos ter a ilusão de que os bancos de traços linguísticos que se formam a cada interação são "bem-comportados" como os que apresentamos acima. Em nosso modelo, apresentamos traços de uma estrutura em apenas duas línguas. Mas, especialmente em uma situação de contato multilinguístico, esse banco de traços deve ser concebido como um repositório de um grande número de estruturas, não apenas de duas línguas, mas de diferentes variedades dessas línguas e de muitas outras línguas. Todas essas estruturas fariam parte da competição. No modelo que propusemos, as estruturas que escolhemos - caso, de fato, tivessem feito parte do banco de traços linguísticos formados pela interação da população colonial - por hipótese, teriam tido boa chance de ser selecionadas, na medida que havia uma convergência entre elas. Entretanto, talvez elas não tenham sido as únicas a exercer um papel na emergência das construções absolutas do português brasileiro. É bastante plausível supor que estruturas das línguas indígenas brasileiras também tenham contribuído para reforçar a seleção, na medida que também participavam do banco de traços. ${ }^{25}$

Mesmo com essas ressalvas, acreditamos que esse é o caminho a ser percorrido na nova linha de pesquisa que estamos aqui propondo, e que estamos chamando história linguística. Como em toda a ciência da história, não devemos esperar resultados exatos. Devemos, sim, procurar interpretar rigorosamente os dados que temos à nossa disposição e levantar hipóteses que nos permitam elaborar um quadro tão preciso quanto possível do que deve ter se passado no processo de formação das línguas.

Valendo-nos da perspectiva lançada por Mufwene ao tratar a evolução linguística como uma resposta adaptativa às diferentes condições ecológicas 
criadas no contato entre populações, delineamos as bases de um projeto de investigação sobre o contato estabelecido entre:

i. o português que aqui chegou com os europeus, em todas as suas variedades dialetais, e já exposto ao contato com um grande número de línguas africanas;

ii. as línguas indígenas nativas de nosso território; e

iii. todas as línguas que foram trazidas pelos africanos para o Brasil, também possivelmente já expostas a complexas situações de multilinguismo em território africano.

Abordar a origem e formação do português brasileiro a partir dessa perspectiva reorienta os debates vigentes sobre a participação das línguas africanas e indígenas na emergência das peculiaridades que distanciam a variedade linguística brasileira da europeia. Primeiramente, ela indica que a participação de outras línguas na formação do português brasileiro vai bem além do léxico. Segundo, ela torna vácuas algumas questões levantadas sobre esse tema porque deixa claro que:

- não se trata de uma mera manutenção de estruturas da matriz europeia, ou de alguma de suas variedades dialetais;

- não se trata de um mero empréstimo de padrōes de construção linguística, que teriam entrado no português brasileiro diretamente de línguas africanas ou indígenas, sem a participação de outras variedades linguísticas;

- não se trata de uma origem crioula, nem de um processo de descrioulização parcial, na medida que não se constituiu, no Brasil colonial, a mesma configuração socioeconomica que levou à formação de crioulos em outras colônias.

Trata-se, na nova perspectiva que propomos, de uma investigação de dupla face: deve começar por uma profunda investigação da história da colonização e das relaçóes socioeconômicas que subjazem as interaçóes entre os membros da população colonial. Paralelamente, deve também debruçar-se sobre as propriedades gramaticais das línguas em contato para delas extrair os possíveis traços que integram o banco de traços explicativo do surgimento de novas variedades linguísticas por meio de competição e seleção. Só assim será possível, a nosso ver, chegar a um entendimento mais claro do que foram os resultados do contato do português europeu com as línguas indígenas da costa, nos 
primeiros anos da exploração. Só assim poderemos delinear o que foi a chamada língua geral paulista, fazendo hipóteses sobre as línguas que participaram de sua formação, sobre a extensão de seu uso no território nacional, e sobre a distância que ela mantinha em relação à língua vernacular que emergia nos centros urbanos da costa brasileira. Só assim vamos poder levantar hipóteses sobre as relações entre a língua geral paulista e a língua geral amazônica, tanto de um ponto de vista linguístico quanto de um ponto de vista sócio-histórico. Só assim vamos poder buscar uma reconstituição das interações linguísticas entre falantes de línguas europeias, de línguas gerais e de línguas africanas, avançando nosso conhecimento sobre a formação do português brasileiro. Essa é a ideia de uma história linguística, de certa maneira já preconizada pela grande linguista brasileira Rosa Virgínia Mattos e Silva, a quem prestamos nossa homenagem.

\section{Notas}

${ }^{1}$ Uma possível exceção talvez seja a interação entre a Linguística e a Antropologia. Muitas vezes chamada Linguística Antropológica, outras vezes chamada Antropologia Linguística, essa interação resulta no "estudo da língua como um recurso cultural e da fala como uma prática cultural” (DURANTI, 1997, p. 2). Esse tipo de estudo tem como objetivo a investigação da língua como um sistema de comunicação que constrói representaçôes da ordem social, tanto entre indivíduos como no mesmo indivíduo. Os pesquisadores dessa área buscam fazer levantamentos das estruturas linguísticas efetivamente usadas por indivíduos de um grupo social, em um dado tempo e em um dado espaço. Esses levantamentos têm uma base etnográfica sólida. Fundamentalmente, a Linguística Antropológica entende a língua como um conjunto de recursos simbólicos usados para a construção do tecido social e das representações individuais dos mundos reais e possíveis. Ao mesmo tempo em que exerce um cuidado metodológico e teórico no tratamento dos fatos da língua, a pesquisa na Linguística Antropológica procura associar o uso da língua a preocupaçōes centrais da Antropologia, por exemplo, a constituição da autoridade, a legitimação do poder, o racismo e os conflitos étnicos, o processo de socialização, as políticas de contato cultural e de mudanças sociais (p. 3-4).

${ }^{2}$ Notem que as análises que realçam as semelhanças do português brasileiro com o português europeu parecem pender mais para uma visão de História como degradação.

${ }^{3}$ Voltaremos a esse assunto mais adiante. 
${ }^{4}$ A partir do final dos anos 1990, vários grandes projetos de pesquisa passaram a incluir nos estudos de Linguística Histórica uma preocupação com a regionalização e com a sócio-história do período em exame. Entre esses projetos, mencionamos, aqui, aquele liderado pelo Prof. Ataliba T. de Castilho, intitulado Projeto para a História do Português Brasileiro, que congrega um grande número de pesquisadores organizados em grupos de trabalho regionais e em grupos de trabalhos temáticos.

${ }^{5}$ Como já dito, há importantes projetos de pesquisa em andamento buscando reconstruir a sócio-história do português brasileiro. Entretanto, seu foco parece estar menos nas relações da história sócio-político-econômica, do que em relaçôes de cunho sócio-demográfico-educacional. Para exemplificar, o Projeto Histórico do Português Paulista (PHPP) estabelece, como o primeiro de seus seis objetivos, "traçar a sóciohistória do português paulista, estudando a ocupação demográfica do território, a formação das variedades culta e popular, e a difusão da variedade popular em direção a Mato Grosso". (CASTILHO, 2009, p. 17). A leitura dos subprojetos que integram o PHPP também deixa entrever um interesse maior pelos fatores sociais (grau de escolaridade, procedência dos diferentes estratos populacionais, etc.) do que pela história das relações de interação entre os vários grupos populacionais.

${ }^{6}$ Dados do IBGE, obtidos no sítio intitulado "Brasil: 500 Anos de Povoamento" disponível em: <http://www.ibge.gov.br/brasil500/index2.html> (acessado em: 9 mar. 2010), mostram que, entre 1531 e 1855, um pouco mais de 4 milhões de africanos foram trazidos para o Brasil, enquanto um pouco menos de 750 mil portugueses entraram na colônia entre 1500 e 1857. Mattos e Silva (2004, p. 125) cita o levantamento apresentado na dissertação de Alberto Mussa ( $\mathrm{O}$ papel das línguas africanas na história do português do Brasil, UFRJ, 1991), segundo o qual, entre 1500 e 1822, 70\% de nossa população era formada por não-brancos. Quanto à população indígena, estima-se que havia 5 milhões de índios vivendo no território nacional no início do século 16.

${ }^{7}$ A noção de pureza racial e pureza linguística estão atreladas à visão de História como degradação, mencionada anteriormente.

${ }^{8}$ Vamos voltar a esse assunto oportunamente.

${ }^{9}$ Entre eles, destacam-se Talmy Givón e Derek Bickerton.

${ }^{10}$ De um ponto de vista linguístico, Petter (2008) sugere que o português brasileiro, o angolano e o moçambicano devem ser entendidos como um continuum linguístico, no sentido de que são línguas que emergiram da relação direta entre as populações do Brasil, de Angola e de Moçambique.

${ }^{11}$ Arruda (2009), sem deixar de reconhecer a importância da tese de Alencastro, reafirma o caráter tripolar do empreendimento comercial dos africanos, ressaltando o papel do pólo europeu no que ele chama "escala final do processo produtivo" (p.511). 
${ }^{12}$ Parte substancial da pesquisa de Naro e Scherre se concentra na variação que existe na concordância nominal e verbal. Mas os autores também têm analisado outros fenômenos do português brasileiro contemporâneo, como o uso da forma pronominal nominativa em posição de objeto, o uso do pronome dativo como sujeito, e o uso do clítico de $3^{\mathrm{a}}$ pessoa se, para a referência à $1^{\mathrm{a}}$ e $2^{\mathrm{a}}$ pessoas. Ver Naro e Scherre (2007, Capítulo 2).

${ }^{13}$ Sapir (1949 [1921], p. 50), com o objetivo de explicar variações dialetais, propõe que todas as línguas sofrem uma deriva que as empurra para longe da norma, a ponto de, algumas vezes, transformá-las em línguas diferentes. Ele parecia cético a respeito do efeito de influências interlinguísticas no processo de mudança. Com base nos estudos históricos de morfologia disponíveis em seu tempo, Sapir sugere que as influências morfológicas de uma língua sobre a outra são apenas superficiais (p. 203-204).

${ }^{14}$ Naro e Scherre apresentam evidências empíricas para fundamentar sua posição. Muitas das características do português brasileiro relacionadas à falta de concordância nominal e verbal - que outros autores têm atribuído ao contato do português com línguas africanas - são atestadas no português medieval e em dialetos do português europeu contemporâneo. Entretanto, Naro e Scherre admitem que, no português brasileiro, a frequência das formas sem flexão é maior do que no português europeu. Por isso, em sua conclusão, eles moderam sua posição. Considerando que, no Brasil, o português foi apropriado por povos de línguas diferentes, em uma situação de multilinguismo e de aquisição de língua por adultos, os autores sugerem que isso pode ter reforçado algumas das características originalmente presentes na variedade europeia da língua, acelerando sua absorção na nova variedade colonial (p. 47-48; 53; 69; 84-85; 148; 180-182). Mesmo assim, os autores mantêm que não houve uma reestruturação na gramática do português na sua apropriação pela população colonial do Brasil.

${ }^{15}$ Dietrich e Noll (2010, p. 81) observam que são inexatas duas das ideias correntes sobre o que seriam as línguas gerais: elas não eram equivalentes ao tupi nem tampouco eram construto dos jesuítas. Nesse sentido, vão contra Mattos e Silva (2004, p. 14), que considera aquilo que ela chama lingua geral da costa como um "tupi jesuítico", construído pela atividade de catequese dos padres europeus que aqui chegaram.

${ }^{16}$ Segundo Rodrigues (2010, p. 27), os índios tupis, que viviam no litoral de São Vicente e na região de Piratininga e do Alto Rio Tietê, eram chamados tupiniquins pelos índios tupinambás que habitavam o Rio de Janeiro. Mas - e aqui reside um outro fator complicador - o termo tupiniquim também servia como etnônimo para os índios do litoral do Espírito Santo e sul da Bahia, que falavam a mesma língua que os tupinambás do Rio de Janeiro e do recôncavo baiano, que os caetés do norte da Bahia, de Sergipe, Alagoas e Pernambuco, e que os potiguares da Paraíba e do Rio Grande do Norte. 
${ }^{17}$ Como visto na nota 16, o tupinambá não era apenas falado no Maranhão, mas em todo o litoral, desde o Rio de Janeiro até o leste do Pará (RODRIGUES, 2010, p. 29).

${ }^{18}$ Isso não significa, no entanto, que achemos que não há diferença entre elas. Mas, a nosso ver, como deve ficar claro ao longo do trabalho, a diferença não pode ser explicada sem discussōes a respeito das diferentes relaçōes que se estabeleceram entre os povos que interagiam nas diferentes regióes em que elas emergiram.

${ }^{19}$ Ver também Rodrigues (1986, p. 99-109).

${ }^{20}$ Especiação é um termo emprestado da genética que denota o processo evolutivo pelo qual as espécies vivas se formam. Para Mufwene, especiação linguística é o processo pelo qual uma língua se divide em outras línguas, por exemplo, o caso do latim, do qual derivaram as línguas românicas.

${ }^{21} \mathrm{O}$ termo usado por Mufwene é feature pool, análogo a gene pool, conceito novamente emprestado da genética: o pool de genes ou pool genético de uma espécie ou população traduz-se no conjunto completo de alelos únicos que podem ser encontrados no material genético de cada um dos organismos vivos de tal espécie ou população. $\mathrm{O}$ termo pool está aqui sendo traduzido por banco.

${ }^{22}$ Como Mufwene alerta, os termos superstrato / substrato são frequentemente usados de maneira imprecisa no estudo do contato linguístico. Em primeiro lugar, considerar o superstrato a língua que funciona como a base da qual provém a maior parte dos itens lexicais é problemático, porque é impossível retirar de uma língua somente os itens lexicais desprovidos da gramática com a qual estão associados. Segundo, no caso dos estudos dos crioulos e de outros vernáculos coloniais, os termos superstrato / substrato, derivados do latim superstratum / substratum, baseiam-se na estratificação social da população em contato e não na ordem de chegada das línguas em contato. No caso do Brasil colonial, as mais de mil línguas indígenas foram as que chegaram primeiro; depois veio o português e, por último, as línguas africanas. Tecnicamente, as línguas africanas deveriam ser consideradas o superstrato - isto é, o último stratum - uma vez que foram as últimas línguas a chegar. Apesar desses problemas, o uso que Mufwene faz desses termos, e que estamos fazendo aqui, segue o convencionado na literatura (p. 288, nota 18).

${ }^{23}$ Explicar todas as propriedades sintáticas e semânticas associadas a esse tipo de construção está fora do escopo deste artigo. Remetemos os leitores a Negrão e Viotti (2010), artigo em que essas propriedades são amplamente discutidas e analisadas. Outra discussão de interesse nesse trabalho é a que mostra que essas construções não podem ser explicadas como resultantes da perda do clítico se, como propõe a literatura linguística brasileira sobre o assunto. 
${ }^{24}$ A hipótese de que o quimbundo tenha tido participação nesse processo encontra sustentação nas pesquisas de Bonvini (2009), que conclui ter sido o quimbundo uma língua veicular, utilizada por participantes da empresa colonial, tanto no Brasil como em Angola.

${ }^{25}$ Lobato (2006), discutindo a influência ameríndia na formação do português do Brasil, também utiliza o traço de deslocamento de constituintes para a periferia esquerda da sentença para desenvolver sua análise. Entre outros dados, ela compara o deslocamento sintático de um subconstituinte do objeto direto para a posição de sujeito no português brasileiro, como observado em (i) e (ii) - deslocamento este que é agramatical no português europeu - ao processo de incorporação ao verbo de um subconstituinte do objeto direto, que ocorre em tupi, guarani antigo e outras línguas ameríndias, como exemplificado em (iii) e (iv), com dados do guarani antigo:

i. Furou o pneu do meu carro.

ii. O meu carro furou o pneu.

iii. a- i- kutúg cyuã $r$ - ayú

$1 /$ Nom $R$ ferir João $R$ veia

Eu feri a veia de João

iv. a- h- ayú-kutúg cyuã

$1 /$ Nom $R$ veia-ferir João

Eu feri a veia de João

A análise de Lobato é a de que a causa da mudança do português brasileiro está no processo de aprendizagem do português como segunda língua por adultos em situação de contato, e não na influência direta de estruturas de uma língua sobre as outras. Mesmo assim, a autora reconhece que existem semelhanças entre os dois processos.

\section{Referências}

ALENCASTRO, L. F. O Trato dos viventes. Formação do Brasil no Atlântico Sul. São Paulo: Cia. das Letras, 2000.

ALTMAN, C. As línguas gerais sul-americanas e a empresa missionária: linguagem e representação nos séculos XVI e XVII. In: FREIRA, José Ribamar Bessa; ROSA, Maria Carlota (Org.). Linguas gerais: política lingüística e catequese na América do Sul no período colonial. Rio de Janeiro: Editora UERJ, 2003. p.57-83.

ARRUDA, J. J. A. O império tripolar: Portugal, Angola, Brasil. In: SCHWARTZ, S.; MYRUP, E. L. (Org.). O Brasil no império maritimo português. Bauru: EDUSC, 2009. p. 509-531. 
BONVINI, E. Línguas africanas e português falado no Brasil. In: PETTER, M. M. T.; FIORIN, J. L. (Org.). África no Brasil. A formação da língua portuguesa. São Paulo: Contexto, 2008. p. 15-62.

BONVINI, E. Revisiter, trois siècles après, Arte da língua de Angola de Pedro Dias S.I. (1697), Première grammaire du Quimbundo. In: PETTER, Margarida; MENDES, Ronald Beline (Ed.). Proceedings of the special World Congress of African Linguistics: Exploring the African language connection in the Americas. São Paulo: Humanitas, 2009. p.15-45.

CHAUDENSON, R. Creolization of language and culture. London/New York: Routledge, 2001.

DeGRAFF, M. Against creole exceptionalism. Discussion note. Language, v.79, p. 391-410, 2003.

DeGRAFF, M. Against creole exceptionalism.(redux). Language, v. 80, p. 834-839, 2004.

DIETRICH, W.; NOLL, V. O papel do tupi na formação do português brasileiro. In: NOLL, V.; DIETRICH, W. (Org.). O português e o tupi no Brasil. São Paulo: Contexto, 2010. p.81-103.

DURANTI, A. Linguistic anthropology. Cambridge/New York: Cambridge University Press, 1997.

FIORIN, J. L. Multidisciplinaridade, interdisciplinaridade e transdisciplinaridade nas ciências humanas. Universidade de São Paulo, Ms., 2012.

GIVÓN, T. Bio-linguistics: The Santa Barbara lectures. Amsterdam/ Philadelphia: John Benjamins Publishing, 2002.

HEINE, B.; KUTEVA, T. Language contact and grammatical change. Cambridge/ New York: Cambridge University Press, 2005.

JESPERSEN, O. Progress in language. Amsterdam: John Benjamins, 1993.

LIPSKY, J. Os primeiros contatos afro-portugueses: implicaçôes para a expansão da língua. In: CARVALHO, A. M. (Ed.). O português em contato. Frankfurt/Madrid: Vervuert/ Iberoamericana, 2009.

LOBATO, L. M. P. Sobre a questão da influência ameríndia na formação do português do Brasil. In: SILVA, Denize Elena Gracia da (Org.). Língua, gramática e discurso. Goiânia: Cânone Editorial/Grupo de Estudos de Linguagem do CentroOeste, 2006. p. 54-86.

MATTOS E SILVA, R. V. Ensaios para uma sócio-história do português brasileiro. São Paulo: Parábola Editorial, 2004. 
MUFWENE, S. S. The ecology of language evolution. Cambridge: Cambridge University Press, 2001.

MUFWENE, S. S. Language evolution. Contact, competition and change. London: Continuum, 2008.

NARO, A. J.; SCHERRE, M. M. P. Origens do português brasileiro. São Paulo: Parábola Editorial, 2007.

NEGRÃO, E. V.; VIOTTI, E. A estrutura sintática das sentenças absolutas no português brasileiro. Linguística, ALFAL, v. 23, p. 61-82, 2010.

NEGRÃO, E. V.; VIOTTI, E. Epistemological aspects of the study of the participation of African languages in Brazilian Portuguese. In: PETTER, M.M.T.; VANHOVE, M. Portugais et langues africaines. Études afro-brésiliennes. Paris: Karthala, 2011. p. 13-44.

PAIXÃO DE SOUSA, M. C. Sintaxe e história do português nos 1600. 2004. Tese (Doutorado) - Universidade Estadual de Campinas, 2004.

PAIXÃO DE SOUSA, M. C. Linguística histórica. In: PFEIFFER, C. C.; NUNES, J. H. (Org.). Introdução às ciências da linguagem: linguagem, história e conhecimento. Campinas: Editora Pontes, 2006. p.11-48.

PAIXÃO DE SOUSA, M. C. Valências verbais no português clássico. Relatório final de pesquisa de Pós-Doutorado, CNPq, Ms., 2008.

PETTER, M. M. T. Variedades linguísticas em contato: português angolano, português brasileiro, português moçambicano. 2008. Tese (Livre Docência) - Universidade de São Paulo, 2008.

RODRIGUES, A. Linguas brasileiras: para o conhecimento das línguas indígenas. São Paulo: Loyola, 1986.

RODRIGUES, A. As línguas gerais sul-americanas. Papia, v.2, n.4, p. 6-18, 1996.

RODRIGUES, A. Tupi, tupinambá, línguas gerais e o português do Brasil. In: NOLL, V.; DIETRICH, W. (Org.). O português e o tupi no Brasil. São Paulo: Contexto, 2010. p.27-47.

SAMPAIO, T. O tupi na geografia nacional. São Paulo: Editora Nacional, (1987 [1901]).

SAPIR, E. Language. An introduction to the study of speech. New York/London: Harcourt Brace Jovanovich, (1949 [1921]).

SILVA NETO, S. A lingua portuguesa no Brasil: problemas. Rio de Janeiro: Acadêmica, 1960. 
SILVA NETO, Seraphim. Introdução ao estudo da língua portuguesa. Rio de Janeiro: Presença, (1980[1950].

WEINREICH, U.; LABOV, W.; NERZOG, M. Fundamentos empiricos para uma teoria da mudança linguistica. São Paulo: Parábola Editorial, (2006[1968]). 